\title{
Macrothink
}

\section{Effect of Using PC Tablets on Perceived Learning Outcomes of Generation Z Trainees}

\author{
Iftikhar Ahmed Khan (Corresponding Author) \\ Naval Forces Institute, United Arab Emirates \\ E-mail: ift.khan@yahoo.com \\ Dr. Vikram Bansal \\ Associate Professor, Lincoln University College, Malaysia \\ E-mail: vikram@lincoln.edu.my
}

Received: December 16, 2017 Accepted: January 6, 2018 Published: January 25, 2018

doi:10.5296/ijld.v8i1.12309 URL: https://doi.org/10.5296/ijld.v8i1.12309

\begin{abstract}
This study aims at analyzing the effects of using PC Tabs on perceived learning outcomes of Generation $\mathrm{Z}$ trainees in a vocational training institute. Generation $\mathrm{Z}$ is the name given to youth born around mid 90s. Having born in and grown up in an era of internet and worldwide web, this generation has become accustomed to e-technology. Their learning preferences have also been conditioned by the e-environment. Resultantly, learning and development experts are focusing on designs and tools matching their learning preferences; adoption of e-learning using PC Tabs for teaching and training is one such step in this direction. This is a correlational study, adopting a mixed method approach, conducted in a Vocational Training Institute in UAE. Sampling frame comprised 100 trainees and their 20 instructors. Purposive sampling technique was used to select $50 \%$ instructors $(\mathrm{N}=10)$ who had experience of delivering training using PC Tabs. Random sampling technique was used to select $60 \%$ of the trainees $(\mathrm{N}=60)$. Data was gathered using informal discussions and a questionnaire. Cronbac's Alpha for the questionnaire was 0.834 . Data was analyzed using SPSS 16. A moderate positive correlation (Pearson's $\mathrm{r}=0.565 ; \mathrm{p}<0.01$ ) was found between use of PC Tabs and better understanding of lecture. Regression analysis indicated that $30.8 \%$ of the variance in better understanding of lecture can be explained by use of PC Tabs by trainees. A moderate positive correlation (Pearson's $r=0.515 ; \mathrm{p}<0.01$ ), was found between use of PC Tabs and trainees' perceived learning. Regression analysis indicated that $25.3 \%$ of the variance in trainees' perceived learning can be explained by use of PC Tabs by trainees. This study concludes that use of PC
\end{abstract}




\section{Macrothink}

International Journal of Learning and Development

ISSN 2164-4063 2018, Vol. 8, No. 1

Tabs have moderate positive effects on better understanding of lecture and trainees' perceived learning outcomes, however, the Generation $\mathrm{Z}$ trainees are tilted more towards interactive learning rather than non-interactive content on PC Tabs. The study recommends that the curriculum must be tailored into an interactive format otherwise it may not accrue desired results in enhancing learning outcomes. This study contributes to the body of practical applied knowledge and has significance for training industry, in general, and vocational training, in specific, which are dealing with Generation $\mathrm{Z}$ trainees.

Keywords: Generation Z, PC tablets, perceived learning outcomes, training 


\section{Macrothink}

\section{Introduction}

\subsection{Social Generations}

The concept of a 'generation' has a long history and can be found in ancient literature (Biggs, 2007). According to Pilcher (1994), a generation is a cohort of people within a delineated population who experience the same significant events within a given period of time, and which according to Jurkievicz \& Brown (1998) is likely to develop distinct preferences or traits that distinguish their feelings toward work and what they desire from work.

Literature on social generations identifies four contemporary generations i.e. Baby Boomers, Generation X, Y and Z, delineated by their birth years (Table 1):

Table 1. Generational birth years

\begin{tabular}{lllll}
\hline & Baby Boomers & Gen X & Gen Y & Gen Z \\
\hline Mark McCrindle (2014) & $1946-1965$ & $1965-1980$ & $1980-1995$ & - \\
Stredwick (2013) & $1946-1964$ & $1965-1979$ & $1980-1990$ & 1990 s - 2000s \\
Knoll Inc (2014) & - & $1965-1978$ & $1979-1997$ & 1998 onwards \\
Gilbert (2011) & - & - & $1982-2000$ & - \\
Watkins \& Neal (2014) & - & - & $1980-2000$ & - \\
Kingston (2014) & - & - & - & After 1995 \\
Horovitz (2012) & & & & Mid-Late 1990s \\
\hline
\end{tabular}

For the purpose of this research, the age bracket for Generation $\mathrm{Z}$ is assumed as those born 1995 and onwards.

\subsection{Generation Z Growing up Environment}

This generation, born 1995 and onwards, has grown up in the era of internet and worldwide web, characterized by 5.1 billion Google searches per day, 4 billion YouTube views, over one billion active Facebook accounts and over one million applications in the iTunes App Store (McCrindle, 2014). Unlike preceding generations, Generation Z youth are using technology since infancy and are normal users of technology (Randy, 2013). Having played with e-devices right from their infancy, they have become the normal users of e-technology. They have a preference for smart interactive devices rather than traditional media and they move very fast with information rather than living with information in bits and pieces. In short, connectivity, interactivity and speed are what they are living with and are getting used to.

\subsection{Learning Characteristics of Generation $Z$}




\section{Macrothink}

International Journal of Learning and Development

ISSN 2164-4063

2018, Vol. 8, No. 1

Growing up and living in the era of IT boom, technology has become the way of life for Generation $\mathrm{Z}$ youth; be it education, professional work or socializing. This normal usage of e-technology has also affected the way Generation $Z$ prefers to learn.

According to Shaw \& Fairhurst (2008), this generation does not respond well to lecture and has become accustomed to interactivity. A study by Feiertag \& Berge (2008) also revealed that Generation $\mathrm{Z}$ youth do not respond well to the lecture, often do not communicate effectively by traditional standards, require information individually tailored to them, and require technology that is available to use. Graber (2014) has supported these assertions by concluding that this generation engages less with traditional learning formats, such as classroom learning. According to McCrindle (2014), this is an emerging generation many of whom prefer to watch a video for summarizing an issue rather than read an article for discussing it.

These characteristics of Generation $\mathrm{Z}$ have created a challenge for educational institutions to mould their traditional philosophy of teaching and learning to suit the requirements of this new generation. Under this emerging environment, there is a realization that future learning and development has to be more digital and collaborative, with social media/collaborative learning, e-learning and increased interactivity (Future Think LLC White Paper, 2009). Graber (2014) suggests that learning and development of this new generation must be based on peer learning, knowledge sharing and collaborative learning in teams by combining traditional instruction with projects and/or simulations. He has stressed the importance of new approach to training delivery that must combine technology (e-learning), classroom instruction and experience-based projects and simulations to drive high levels of engagement, achieve learning outcomes and increase the retention of key competencies and knowledge.

Sensing this emerging challenge, educational institutions have adopted e-technology in imparting learning; most common e-tool that educational institutions have adopted are PC Tabs. This quick adoption and use of PC Tabs for teaching and learning has led to many experiences, queries and concerns among educationist and trainers, ranging from satisfaction to caution.

\subsection{Use of PC Tabs for Imparting Learning to Generation $Z$}

Since its appearance, PC Tab has rapidly found its usage in many walks of life. Use of PC Tabs in education has become increasingly common (Fischman \& Keller, 2011). A survey conducted by Nielsen (2010) indicated that the demographics of PC Tabs users make it sensible to introduce and integrate PC Tabs in higher education.

Studies show that the impact of handheld mobile devices on educational practice continues to be an area of considerable interest in both the research and practice of education (Ally, 2009). Various studies have been conducted so far to analyze the effectiveness of PC Tabs towards enhancing learning. While some of these studies have reported the effectiveness of PC Tabs in enhancing learning outcomes, some of the studies claim that effectiveness of PC Tabs in enhancing learning is still not established.

Reid \& Ostashewski (2011) have reported successful use of PC Tabs into two elementary 
school classrooms to support the development of student digital storytelling skills. As for enhanced learning outcomes, a survey with 209 students found a high correlation between engagement with PC Tabs and learning outcomes (Diemer et al, 2012). Similarly, Bennett (2012) has reported positive learning outcomes by use of PC Tabs in elementary education settings, recommended organizing PC Tabs to show what is required to be shown, and accessing internet through school's Wi-Fi to ensure controlled access. In a paper presented in ELLTA Conference 2014 (Penang), the researchers reported that use of PC Tabs for teaching and delivering training was increasing and that integration of PC Tabs in classrooms had indicated positive impact on teaching and learning (Ling, Le \& Kaur, 2014).

Among the studies reporting positive outcomes, some of the researchers have focused on students' positive perceptions and attitudes towards use of PC Tabs for learning. BizEd Magazine (2011) has reported that $75 \%$ of students at Oklahoma State University believed that tablet improved their learning, and 97\% indicated they would prefer to continue taking classes that integrated tablet technology. In studies conducted by Brand et al (2011) and Perez et al (2011), PC Tabs were found to highly engage and potentially enhance students' learning experience. Similarly, studies conducted by Rossing et al (2012) and Wakefield \& Smith (2012) revealed that students were found to hold a positive attitude about towards using PC Tabs in their learning. Audi \& Gouia-Zarrad (2013) reported a study on using PC Tabs for teaching of mathematics class in American University of Sharjah, with course content in pdf form, conducting quizzes, referring to book material, and real time communication with students. They have reported that most of the students found PC Tabs class engaging and agreed that the PC Tabs class presented the class content in a better way. Going a step further than perceptions and attitudes, Goral (2011) has reported that use of tablets technology for learning can lead to enhanced creativity, critical thinking, substantial cost savings and improved interaction among students and faculty.

Alongside the success stories of adoption of PC Tabs for enhanced learning, there are incidents which have cautioned that adoption of PC Tabs technology just for the sake of it may not prove very useful. Murphy (2011) has predicted that increasing popularity of these devices will likely lead to even greater adoption among students at the post-secondary level over the coming years but he has cautioned that adopting technology for technology's sake does not guarantee improved learning outcomes or an enriching educational experience.

Besides success and caution, some of the research has reported another aspect of use of PC Tabs for imparting learning in classroom i.e. its distraction effect. Kay \& Lauricella (2011a, 2011b), studying the use of laptops in imparting learning, have said that laptops provided benefits, including improved note-taking, improved organizational skills and improved collaboration among students. They also found that use of laptop posed challenges including distractions caused by students using instant messaging applications, playing games and watching movies instead of focusing on the class. In other instances, researchers have argued that although PC Tabs were found to motivate students (Kinash et al, 2012), some resistance was found because it could create a distraction (Wakefield \& Smith, 2012).

Though most of the literature claims success with use of PC Tabs in one form or the other, 
some of the instances have reported unsuccessful results as well. Culén \& Gasparini (2011) have reported two pilot studies on trying out a digital curriculum on PC Tabs for a Geology Class (40 students and their instructor), in which the curriculum for the course consisted of book chapters, lecture slides, maps and academic papers. They have reported that introduction of this technology had not been a success due to time pressures. In another incident of a design-based study, the students were not convinced that PC Tabs made any difference in their learning. (Brand et al, 2011).

Along with the research proving or disproving the usefulness of PC Tabs in imparting learning, most of the studies have remained inconclusive in establishing the effectiveness of PC Tabs. Nguyen, Barton \& Nguyen (2015) concluded from their research that from the student perspective, PC Tabs were found to enhance the learning experience but not necessarily lead to better learning outcomes; from the staff perspective, the PC Tabs were found to offer benefits associated with electronic information dissemination, academic administration and professional development support. However, they have professed that while PC Tabs had the potential to offer benefits, it was not clear how best to align and integrate it within the academic programmes. They have professed that research had been inconclusive about the relationship between the increasing use of PC Tabs, changing teaching and learning practices and learning outcome. Perez et al (2011) have reported that while students were positive with using PC Tabs in their learning, no evidence was found to associate their PC Tabs use with better learning outcomes. Similarly, Diemer, Fernandez \& Streepey (2013) have said that despite their rapid adoption, the extent to which PC Tabs increased student engagement and learning was not well understood. However, they have added that students, who reported a high level of engagement while using PC Tabs, reported a high level of learning as well. In another study by Sloan (2012), the use of eTextbook, an iPad app, did not have a negative impact on academic performance of students. Since the introduction of PC Tabs in teaching and learning is a recent initiative, studies will have to continue to find its usefulness and effectiveness. According to Wan $\mathrm{Ng}$ (2014), we need to look at e-learning and review the way students make use of and learn with digital technologies in $21^{\text {st }}$ century.

\subsection{Conclusion from Existing Literature}

Literature on Generation $\mathrm{Z}$ suggests that they are natural and avid users of e-technology and that they prefer e-tools over traditional means in all walks of their lives. This aptitude and affinity for technology transcends to the field of education and learning as well, where the available evidence suggests that Generation $\mathrm{Z}$ prefers e-technology over traditional means. In this backdrop, e-tools especially PC Tabs have become very popular for imparting learning in schools and colleges. While some of the research suggests that PC Tabs are effective in delivering learning in classroom, there are studies which have remained inconclusive in determining the effects of using PC Tabs on enhancing learning outcomes. Resultantly, research continues on discovering the effects of PC Tabs on learning and suggesting optimum ways to leverage the benefits of this e-technology. 


\section{$\Lambda$ Macrothink}

\section{Research Methodology}

\subsection{Research Background}

Given the perceived positive effects PC Tabs can create in teaching and learning, a Vocational Training Institute in UAE adopted PC Tabs for training delivery. Trainees in this institute had 1995-1996 as their birth years; making them the earlier members of Generation Z. They were exposed to use of PC Tabs for around 3 years. These PC Tabs were used for training delivery, content was based on course material converted to pdf form, mostly e-copy of books with some expandable diagrams and very few embedded videos relevant to the text, some end of chapter questions were also made interactive. After using the PC Tabs for training delivery, varying experiences were reported both by instructors and trainees. Both the sides reported a mix of responses, ranging between successful and unsuccessful experiences. This research was carried out with an aim of finding out trainees' and instructors' experiences and effects on learning outcomes.

\subsection{Research Objective}

This research is aimed at studying the impact of usage of PC Tabs for training delivery in a vocational training environment, where focus was equally divided between academic as well as skill-based learning. The objective of this research is to:

"Analyze the effects of using PC Tabs on perceived learning outcomes of Generation Z trainees in a vocational training institute."

\subsection{Research Design}

This research is 'correlational' in nature, which is aimed at discovering or establishing relationship, association or interdependence between two or more aspects of a situation or phenomenon (Kumar, 2014). In order to find answers to the research questions, this study adopted a mix-method approach i.e. a mix of qualitative and quantitative approaches. The qualitative approach provided subjective insight into experiences of instructors conducting training using PC Tabs; quantitative approach captured the useful data from trainees through surveys which helped in reaching a conclusion. Also, the mixed-method approach helped in cross-checking the findings through triangulation. With regard to point in time, this is a cross-sectional research, aimed at gathering data from the perspectives of many people at a particular point in time. From the perspective of knowledge generation, this research is aimed at generating Mode-2 knowledge, which is practical applied knowledge coming from collaborating with practitioners (Gibbons \& Limoges et al, 1994; Ziman, 2000).

\subsection{Hypothesis}

The hypothesis of this study is:

"Use of PC Tabs for delivering training has positive correlation with Gen Z trainees' perceived learning outcomes." 


\section{Macrothink}

\subsection{Research Sample and Sampling Technique}

The target population comprised trainees undergoing training and their instructors in a Vocational Training Institute.

Instructors Instructors had an average professional career span of 20 years, employed for conducting training as Subject Matter Experts. A total of 20 instructors were employed for delivering this training. They were instrumental in transforming training to PC Tabs. Purposive sampling technique was used to select $50 \%$ of instructors who had either completed or were in the process of delivering training of their respective modules. This resulted in selection of 10 instructors $(\mathrm{N}=10)$ as research sample out of the sampling frame.

Trainees Subjects of the research were trainees in a vocational training institute, with average birth year 1995. The sampling frame comprised 100 trainees. They were in the final year of their professional training. They had been exposed to use of PC Tabs for training delivery for 3 years. $60 \%$ of the trainees $(\mathrm{N}=60)$ were randomly selected for the purpose of research.

\subsection{Data Gathering and Analysis}

Data was gathered in the real time training settings of the instructors and trainees. In that, informal discussions were held with instructors, as and when opportunity presented itself, to capture open and in-depth experience of using the PC Tabs. The discussion questions were focused on aspects like effectiveness of PC Tabs in delivering training in the institute in the present form (with non-interactive e-copy content) and how best to improve the use of PC Tabs for training delivery. The crux of the discussion was transcribed and shown to the instructors for approval.

Data from trainees was gathered through a questionnaire comprising 10 statements, asking their experience of using the PC Tabs in present form (non-interactive, e-copies) and their views on adding specific features to PC Tabs for better training delivery. Trainees were asked to rate the statements on Likert's 5-point scale ranging from Highly Agree $=5$ to Highly Disagree $=1$. The data was analyzed using SPSS-16. Reliability and consistency was measured through Cronbac's Alpha value, which was 0.834, showing good internal consistency (George \& Mallery, 2003). (Table-2)

Table 2. Cronbac's Alpha values

\begin{tabular}{ll}
\hline Cronbac's Alpha Value & Internal consistency \\
\hline$\alpha \geq 0.9$ & Excellent (High-Stakes testing) \\
$0.7 \leq \alpha<0.9$ & Good (Low-Stakes testing) \\
$0.6 \leq \alpha<0.7$ & Acceptable \\
$0.5 \leq \alpha<0.6$ & Poor \\
$\alpha<0.5$ & Unacceptable \\
\hline
\end{tabular}




\section{1l Macrothink}

\section{Findings}

\subsection{Discussions with Instructors}

Instructors were asked about their experiences of delivering training using PC Tabs from teaching point of view. As mentioned earlier, the discussion questions were focused on aspects like effectiveness of PC Tabs in delivering training in the institute in their present form (with non-interactive e-copy content) and how best to improve the use of PC Tabs for improved training delivery.

To the question on efficacy of PC Tabs with non-interactive e-copy content, almost all the instructors commented that use of PC Tabs was yielding very little benefit towards enhancing learning outcome. Some of the responses were:

"I think PC Tabs with non-interactive e-copy content have some utility but these do not bring about any significant improvement in training delivery. These PC Tabs, at the moment, have power point presentations and handouts which were used effectively even before introduction of the PC Tabs."

"PC Tabs in their present form offer very little improvement in training delivery as students do not find anything on PC Tabs that is different or more useful than what instructor is saying in the class. Usually, after some time, students turn off the PC Tabs and start listening to the instructor."

"The only benefit I see is the elimination of paper handouts. Also, the good thing is that students now have diagrams and video clips available at some places alongside the text. They can expand the diagrams and see video clips for better understanding, but nothing more than this."

"These PC Tabs have just replaced the handouts, which students can carry these easily along with them and study the course material after formal training time."

To the question about suggesting ways to improve the use of PC Tabs, all the instructors recommended having interactive content related to lecture which instructor and students could use for better learning. Some of the responses were:

"I suggest we have interactive content available on PC Tabs which instructor and students can use to improve learning in classroom. This can include animated explanations, more information, examples, self assessment, idea sharing etc."

"Interactive content would be better for achieving enhanced learning outcomes. This must include animations, short quizzes, access to relevant material, spot tests etc."

"Interactive content would keep the students interested and engaged in learning which has a direct impact on enhancing learning outcomes. This must comprise animations, simulations, practical exercises etc."

"I think PC Tabs with interactive content can achieve better learning outcome, provided the content is tailored to the scope and depth of lecture and instructor controls the access to 


\section{Macrothink}

links."

\subsection{Trainees' Questionnaire}

A summary of descriptive statistics is shown in the table below (Table-3).

Table 3. Summary of descriptive statistics

\begin{tabular}{|c|c|c|c|}
\hline Variables & $\mathbf{M}$ & SD & Result \\
\hline Use of PC Tabs in Classroom & 2.95 & 1.21 & $\begin{array}{l}35 \% \text { of trainees agreed that they regularly used PC Tabs in } \\
\text { classroom whereas } 30 \% \text { reported neither agree/disagree. }\end{array}$ \\
\hline Preference of PC Tabs over handout & 2.15 & 1.23 & $\begin{array}{l}41.7 \% \text { of the trainees highly disagreed that they prefer PC } \\
\text { Tabs over handout; } 23.3 \% \text { did not agree }\end{array}$ \\
\hline $\begin{array}{l}\text { Better understanding of lecture } \\
\text { using PC Tabs }\end{array}$ & 2.38 & 1.09 & $\begin{array}{l}35 \% \text { of the trainees neither agreed/disagreed that they } \\
\text { understand lecture better by using PC Tabs; } 25 \% \\
\text { disagreed to this. }\end{array}$ \\
\hline Use of PC Tabs for revision & 2.63 & 1.22 & $\begin{array}{l}35 \% \text { of the trainees neither agreed/disagreed that they use } \\
\text { PC Tabs for revision; } 16.7 \% \text { disagreed. }\end{array}$ \\
\hline PC Tabs helpful in learning & 2.62 & 1.02 & $\begin{array}{l}41.7 \% \text { of the trainees neither agreed/disagreed that } \mathrm{PC} \\
\text { Tabs was helping them in better learning, only } 20 \% \text { agreed } \\
\text { to it. }\end{array}$ \\
\hline Better learning with animations & 3.32 & 1.22 & $\begin{array}{l}33.3 \% \text { trainees agreed that their learning would improve if } \\
\text { the PC Tabs have animations related to lecture, } 26.7 \% \\
\text { were not sure. }\end{array}$ \\
\hline Better learning with video clips & 3.48 & 1.26 & $\begin{array}{l}23.3 \% \text { of trainees highly agreed, and } 33.3 \% \text { agreed, that } \\
\text { their learning would improve if the PC Tabs have videos } \\
\text { related to lecture, } 23.3 \% \text { were not sure }\end{array}$ \\
\hline $\begin{array}{l}\text { Better learning with interactive } \\
\text { exercises }\end{array}$ & 3.73 & 1.13 & $\begin{array}{l}31.7 \% \text { trainees highly agreed, and } 28.3 \% \text { agreed, that their } \\
\text { learning would improve if the PC Tabs have practical } \\
\text { exercises related to lecture, } 25 \% \text { were not sure }\end{array}$ \\
\hline Better learning with simulations & 3.93 & 1.07 & $\begin{array}{l}38.3 \% \text { trainees highly agreed, and } 28.3 \% \text { agreed, that their } \\
\text { learning would improve if the PC Tabs have simulations } \\
\text { related to lecture, } 25 \% \text { were not sure }\end{array}$ \\
\hline Better Learning with self-test & 4.07 & 1.13 & $\begin{array}{l}48.3 \% \text { trainees highly agreed, and } 25 \% \text { agreed, that their } \\
\text { learning would improve if the PC Tabs have simulations } \\
\text { related to lecture, } 15 \% \text { were not sure }\end{array}$ \\
\hline
\end{tabular}

Trainees' responses to questionnaire statements are shown by a bar graph (Graph-1). 


\section{Macrothink}

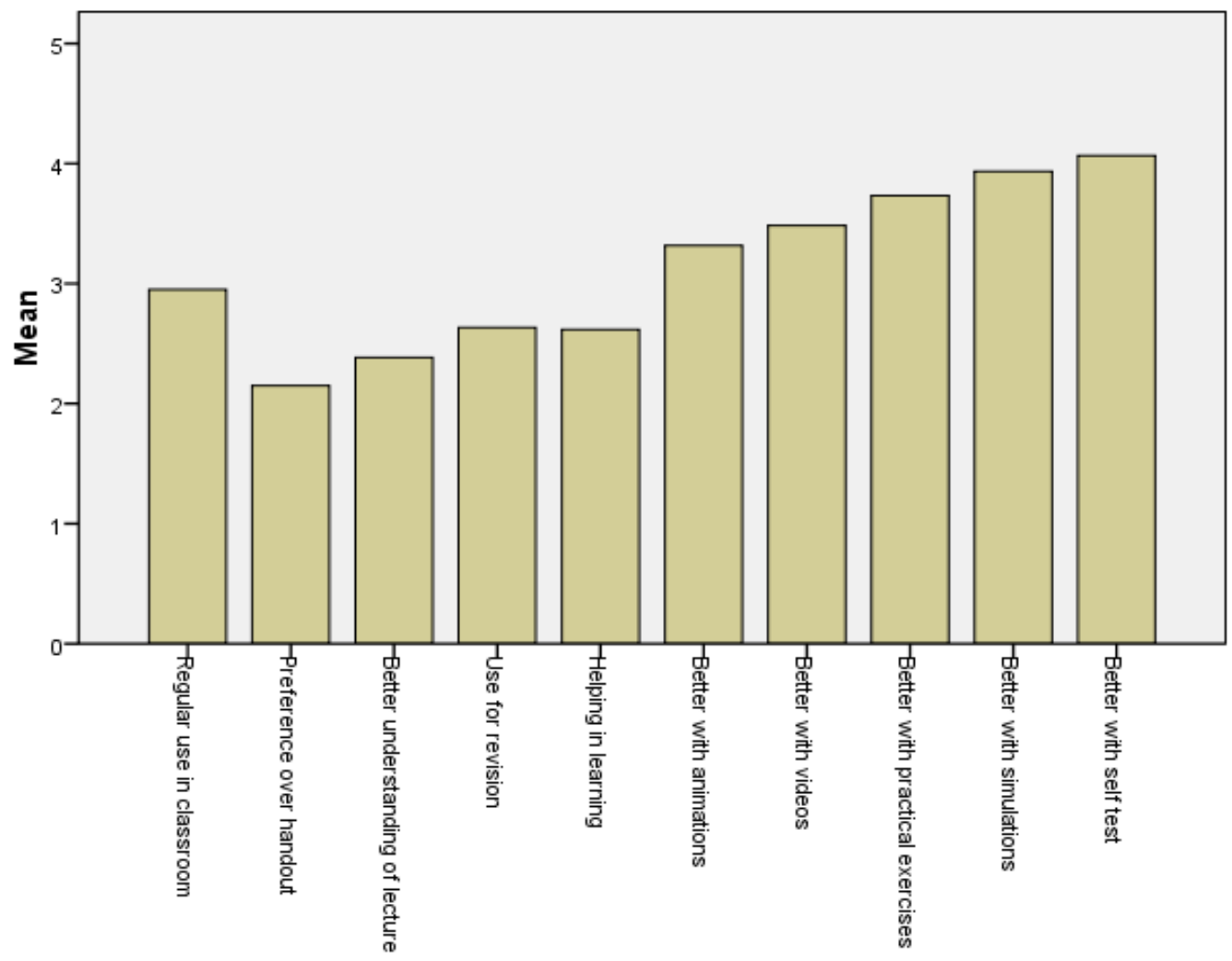

Graph 1. Result of trainees' responses on questionnaire

As seen in the graph, trainees' satisfaction with PC Tabs in present form (non-interactive, e-copy) mostly ranges between 2 (Disagree) and 3 (Neither Agree / Disagree). Whereas, their views on added interactive features in PC Tabs for improved training delivery ranges between 3 (Neither Agree / Disagree) and 4 (Agree). This shows their general preference for PC Tabs with interactive contents.

\subsection{Effect of Using PC Tabs on Understanding of Lecture}

Correlation analysis between use of $\mathrm{PC}$ Tabs $(\mathrm{N}=60, \mathrm{M}=2.95, \mathrm{SD}=1.21)$ and understanding of lecture $(\mathrm{N}=60, \mathrm{M}=2.38, \mathrm{SD}=1.09)$ revealed Pearson's $\mathrm{r}=0.565(\mathrm{p}<0.01)$, showing moderate positive correlation. This shows that students who use PC Tabs regularly are likely to understand lecture better. Regression analysis revealed $F(1,58)=27.267, p=<0.01 ; R$ square $=0.320$, Adjusted R Square $=0.308$. This indicates that $30.8 \%$ of the variance in better understanding of lecture can be explained by use of PC Tabs by trainees.

\subsection{Effect of Using PC Tabs on Trainees' Perceived Learning Outcome}

Correlation analysis between use of $\mathrm{PC}$ Tabs $(\mathrm{N}=60, \mathrm{M}=2.95, \mathrm{SD}=1.21)$ and perceived learning outcome $(\mathrm{N}=60, \mathrm{M}=2.62, \mathrm{SD}=1.02)$, revealed Pearson's $\mathrm{r}=0.515(\mathrm{p}<0.01)$, showing moderate positive correlation. This shows that students who use PC Tabs regularly are likely to achieve better overall learning. Regression analysis revealed $\mathrm{F}(1,58)=20.941$, $\mathrm{p}=<0.01 ; \mathrm{R}$ square $=0.265$, Adjusted R Square $=0.253$. This indicates that $25.3 \%$ of the 
variance in trainees' perceived learning can be explained by use of PC Tabs by trainees.

\section{Conclusion}

Findings from discussions with instructors revealed that PC Tabs with non-interactive e-copy content were yielding very little benefit towards enhancing learning outcome. Instructors felt that these PC Tabs had limited utility, not enough to bring about any significant improvement in training delivery. They reported that students did not find anything new on PC Tabs that was different or more useful than what was there before adoption of the PC Tabs, which led to an average trainee interest in using PC Tabs during the lecture. Almost all the instructors recommended having interactive content related to lecture on PC Tabs which instructor and students could use to enhance learning. The interactive content recommended by instructors included animated explanations, practical examples, self assessment quizzes, idea sharing, access to relevant material, simulations, practical exercises etc.

Findings from trainees gave a comprehensive picture about the usefulness of PC Tabs from two perspectives; (1) usefulness of PC Tabs in their present form, (2) enhanced impact if these PC Tabs had interactive content. Since trainees belonged to Generation Z, they were accustomed to interactivity and prefer to learn by non-traditional means. Though trainees reported a mixed response on using PC Tabs in classroom, they felt that PC Tabs with non-interactive e-copy content failed to attract their attention and create meaningfulness for them. Due to this average level of motivation, trainees did not use PC Tabs very frequently in classroom, which was due to the fact that PC Tabs had no additional features which could support learning. Supporting this situation, research showed a moderate positive correlation between usage of PC Tabs in classroom and better understanding of lecture, which could be attributed to lack of interactivity and other supporting features. When it comes to effect of using PC Tabs on trainees' perceived learning, a moderate positive correlation indicated that PC Tabs could not substantially enhance overall learning, which again could be attributed to non-interactive content.

As for the aspect of the perceived effectiveness of PC Tabs with interactive contents, trainees' responses indicated their preference for interactive content comprising animations, video clips, practical exercises, simulations and self-test features. This perceived usefulness of PC Tabs with interactive contents indicates that PC Tabs could best be used if these interactive features are provided for.

Overall findings reveal that use of PC Tabs for delivering training to Generation $\mathrm{Z}$ trainees has moderate positive correlation with their understanding of lecture and perceived learning outcome. However, PC Tabs could best be used for training delivery / imparting learning provided these have the curriculum in an interactive format, supported by animations, videos, practical exercises, simulations and self-test features tailored to the objective and scope of the training / learning objective. This also leads to a conclusion that adopting PC Tabs for the sake of adopting it, without any value-adding interactive features, is unlikely to yield the desired results.

This study recommends that: 
a. Since Generation $\mathrm{Z}$ trainees / students are accustomed to using e-technology in their all walks of life, adoption of e-tools for delivering training / imparting learning would be a natural response to the emerging challenge.

b. PC Tab is a very useful tool for delivering training / teaching, however, its usefulness depends on the content it contains. The content provided on these PC Tabs must be interactive in nature, and not just non-interactive e-copy of books.

c. The interactive content must be structured to suit the objective and scope of the lecture. This would require radical re-thinking and re-visiting the way in which training / teaching content is designed and delivered. This would mean much more than converting handouts / text books into e-copy form along with a few interactive features like videos and quizzes.

\section{References}

Ally, M. (2009). Mobile learning: Transforming the delivery of education and training. Athabasca, AB: Athabasca University Press.

Audi, D. \& Gouia-Zarrad, R. (2013). A new dimension to teaching mathematics using iPads. Procedia-Social and Behavioral Sciences, 103, 51-54. https://doi.org/10.1016/j.sbspro.2013.10.306.

Bennett, K. R. (2012). Less than a class set. Learning \& Leading with Technology, 39(4), 22-25. ISSN-1082-5754.

Biggs, S. (2007). Thinking about generations: Conceptual positions and policy implications. Journal of Social Issues, 63(4), 695-711. https://doi.org/10.1111/j.1540-4560.2007.00531.x

Brand et al. (2011). iWant does not equal iWill: Correlates of mobile learning with iPads, e-textbooks, Blackboard Mobile Learn and a blended learning experience. Paper presented at ASCILITE 2011-The Australasian Society for Computers in Learning in Tertiary Education. $\begin{array}{llllll}\text { Retrieved on } & 5 & \text { Nov } & 2017 & \text { from }\end{array}$ http://www.leishman-associates.com.au/ascilite2011/downloads/papers/Brand-full.pdf.

Bruce, H. (2012). After Gen X, Millennials, what should next generation be? USA Today, May 4, 2012. Retrieved on 7 Nov 2017 from http://en.wikipedia.org/wiki/Generation_Z.

Culén, A. L., \& Gasparini, A. (2011). iPad: A new classroom technology? A report from two pilot studies. INFuture Proceedings, 199-208.

Diemer, T. T., Fernandez, E. \& Streepey, J. W. (2012). Student perceptions of classroom engagement and learning using iPads. Journal of Teaching and Learning with Technology, l(2), 13-25.

Emelo, R. (2013). Forget Gen Y. Get ready for Gen Z. Retrieved on 10 November 2017 from http://www.astd.org/Publications/Blogs/Human-Capital-Blog/2013/06/Forget-Gen-Y-Get-Rea dy-for-Gen-Z.

Fischman, J., \& Keller, J. (2011). College tech goes mobile. The Chronicle of Higher Education, 58(50). 
Feiertag, J. \& Berge, Z. (2008). Training Generation N: How educators should approach the Net Generation. Education + Training, 50(6), 457-464. Maryland: Emerald Group Publishing Limited. https://doi.org/10.1108/00400910810901782.

Future Think LLC (2009). The Future of learning \& development: Trends, topics \& tools to stay ahead of the curve. White Paper, October 2009. Retrieved on 6 Nov 2017 from www.trainingindustry.com.

George, D., \& Mallery, P. (2003). SPSS for Windows step by step: A simple guide and reference. 11.0 update (4th Ed.). Boston: Allyn \& Bacon. ISBN-10:0205375529.

Gibbons, M. I. et al. (1994). The new production of knowledge: The dynamics of science and research in contemporary societies. London: Sage. ISBN O-8039-7793-X.

Gilbert, J. (2011). The Millennials: A new generation of employees, a new set of engagement policies. Ivey Business Journal, 75(5), 26-28.

Goral, T. (2011). Take II Tablets. University Business, January 2011, 46-49.

Graber, S (2014). Learning \& development for the next generation of leaders. Training Industry, May 22, 2014. Retrieved on 7 Nov 2017 from http://www.trainingindustry.com/professional-education/articles.

Horovitz, B. (2012). After Gen X, Millennials, what should next generation be? USA Today, May 4, 2012. Retrieved on 12 Nov 2017 from http://usatoday30.usatoday.com/money/advertising/story/2012-05-03/naming-the-next-genera tion/54737518/1

ITU (2012). The state of broadband 2012: Achieving digital inclusion for All. A report by the Broadband Commission September 2012, Pp. 6.

Jurkiewicz, C. E. \& Brown, R.G. (1998). GenXers vs. Boomers vs. Matures: Generational comparisons of public employee motivation. Review of Public Personnel Administration, 18, 18-37. https://doi.org/10.1177/0734371X9801800403

Kay, R. H., \& Lauricella, S. (2011a). Exploring the benefits and challenges of using laptop computers in higher education classrooms: A formative analysis. Canadian Journal of Learning and Technology, 37(1), 1-18. http://dx.doi.org/10.21432/T2S598.

Kay, R. H., \& Lauricella, S. (2011b). Unstructured vs. structured use of laptops in higher education. Journal of Information Technology Education, 10, 2011. Retrieved on 6 Nov 2017 from https://www.informingscience.org/Publications/1363. https://doi.org/10.28945/1363 .

Kinash, S., Brand, J. \& Mathew, T. (2012). Challenging mobile learning discourse through research: Student perceptions of Blackboard Mobile Learn and iPads. Australasian Journal of Educational Technology, 28(4), 639-655. https://doi.org/10.14742/ajet.832.

Kingston, A. (2014). Get Ready for Generation Z. They're Smarter than Boomers, and way more Ambitious than the Millennials. Retrieved on 8 Nov 2017 from http://www.macleans.ca/society/life/get-ready-for-generation-z/ 
Knoll, Inc. (2014). What comes after Y? Generation Z: Arriving to the office soon. Knoll Workplace research, Pp. 2.

Kumar, J. (2014). Research methodology (4 ${ }^{\text {th }}$ ed.). Los Angeles: Sage Publications Ltd, pp-13.

Lau, E. (2014). Asian engineering students' perception on lecture capture technology. Proceedings of ELLTA 2014 Conference, Penang. ISBN 978-967-399-223-2.

Ling, W., Le, W. \& Kaur, T. (2014). Integration of iPads in education. Proceedings of ELLTA 2014 Conference, Penang. ISBN 978-967-399-223-2.

McCrindle, M. (2014). The ABC of YYZ; Understanding global generations ( $3^{\text {rd }}$ ed.). New South Wales: McCrindle Research Ltd.

Murphy, G. D. (2011). Post-PC devices: A summary of early iPads technology adoption in tertiary environments. E-Journal of Business Education \& Scholarship of Teaching, 5(1), 18-32.

Nielsen (2010). The connected devices age: iPads, Kindle, Smartphones and the connected $\begin{array}{llllll}\text { consumer. } & \text { Retrieved } & \text { on } & 10 & \text { Nov } & 2017 \text { from }\end{array}$ http://blog.nielsen.com/nielsenwire/consumer/the-connected-devices-age-iPads-kindles-smart phones-and-the-connected-consumer/.

Nguyen, L., Barton, S. M., \& Nguyen, L. T. (2015). iPads in higher education: Hype and hope. British Journal of Educational Technology, 46(1), 190-203. https://doi.org/10.1111/bjet.12137.

Perez, O. A., Gonzalez, V., Pitcher, M. T. \& Golding, P. (2011). Work in progress: Analysis of mobile technology impact on STEM based courses; specifically introduction to engineering in the era of the iPads. Paper presented at the 118th ASEE Annual Conference and Exposition, Vancouver, BC, Canada, June 26-29, 2011.

Pilcher, J. (1994). Mannheim's sociology of generations: An undervalued legacy. British Journal of Sociology, 45(3), 481-495. https://doi.org/10.2307/591659.

Reid, D. \& Ostashewski, N. (2011). iPads in the classroom - New technologies, old issues: Are they worth the effort? Paper presented at the World Conference on Educational Multimedia, Hypermedia and Telecommunications, I, 2011, 1689-1694.

Rossing, J. P. et al. (2012). iLearning: The future of higher education? Student Perceptions on Learning with Mobile Tablets. Journal of the Scholarship of Teaching and Learning, 12(2), 1-26.

Schools release iPad studies. (2011) BizEd Magazine, 60-63.

Shaw, S. \& Fairhurst, D. (2008). Engaging a new generation of graduates. Education and Training, 50(5), 366-78. Retrieved on 15 Nov 2017 from https://eric.ed.gov/?id=EJ801305. https://doi.org/10.1108/00400910810889057. 


\section{Macrothink}

International Journal of Learning and Development

ISSN 2164-4063 2018, Vol. 8, No. 1

Stredwick, J. (2013). An Introduction to HR Management $\left(3^{\text {rd }}\right.$ ed.). New York: Routledge, Pp 318.

Sloan, R. H. (2012). Using an eTextbook and iPad: Results of a pilot program. Journal of Educational Technology Systems, 41(1), 87-104. http://dx.doi.org/10.2190/ET.41.1.g.

Wakefield, J. \& Smith, D. (2012). From Socrates to satellites: iPads learning in an undergraduate course. Creative Education, 3(5), 643-648. http://dx.doi.org/10.4236/ce.2012.35094.

Wan Ng (2014). E-learning, V-learning, M-learning, D-learning, o-learning, P-learning, U-learning, F-learning: What are the Implications for Learning Theories, Learners and Pedagogy, Integration of iPads in Education. Proceedings of ELLTA 2014 Conference, Penang. ISBN 978-967-399-223-2.

Watkins, M. \& Neal, P. J. (2014). Millennial in training. Workforce, 94(1), January 2015.

World Bank (2012). Maximizing mobile. Retrieved on 12 Nov 2017 from http://www.worldbank.org.

Ziman, J. (2000). Real science: What it is and what it means. Cambridge: Cambridge University Press.

\section{Copyright Disclaimer}

Copyright for this article is retained by the author(s), with first publication rights granted to the journal.

This is an open-access article distributed under the terms and conditions of the Creative Commons Attribution license (http://creativecommons.org/licenses/by/4.0/). 